\section{THE EDINBURGH CHAIR OF PHYSTOLOGY.}

$T \mathrm{HE}$ following is the closed list of candidates for the chair of Physiology in the University of Edinburgh, rendered vacant by the death of Prof. Rutherford: Dr. Wace Carlier and Dr. Noel Paton, Edinburgh; Prof. Reid, Dundee; Prof. Schäfer, London; Prof. G. N. Stewart, Cleveland, Ohio ; Prof. Stirling, Manchester ; Prof. Anderson Stuart, Sydney.

The Edinburgh chair of Physiology, though founded in 1742 , has almost invariably been occupied by physicians -amongst others Cullen, Gregory, Alison, and Rutherford's immediate predecessor, Hughes Bennett. The one striking exception in addition to Rutherford is Allen Thomson, the famous anatomist. Rutherford's time having been largely devoted to teaching, it may be truly said that Edinburgh, from a physiological point of view, has still its spurs to win. Had other counsels prevailed in 1855 , Edinburgh might have secured the services of Sharpey, and long ere this been as famous for its physiological as for its anatomical school.

The mistakes of 1855 (when the services of Agassiz, as well as those of the founder of English physiology, were declined) are not likely to be repeated, for it is now sufficiently evident to all concerned that if the Scottish capital is to maintain and extend her medical school, she must fill her Science chairs with men who, in addition to great teaching powers, have gained by their researches a world-wide reputation. As it happens, the Court of Curators, in whose hands the appointment lies, will have the opportunity of largely atoning for the past by placing at the head of the physiological department a pupil of Sharpey's who, by his success as a teacher and worker, has placed himself in the very foremost rank of British physiologists.

In the interests of science and of the great imperial seat of learning, we, with Lord Lister, "venture to express the earnest hope that Prof. Schäfer's paramount claims may receive their due recognition."

\section{NOTES.}

THE second (or ladies') conversazione of the Royal Society will take place on June $2 \mathrm{I}$.

AT the next meeting ( $J$ une 8 ) of the London Mathematical Society, the President, Lord Kelvin, G.C.V.O., proposes to read a paper "On solitary waves, equivoluminal and irrotational, in an elastic solid." At the previous Council meeting, the election of the sixth De Morgan medallist of the Society will take place, and the announcement of the result will be made to the members present at the general meeting. The presentation of the medal will be made at the annual meeting in November next.

THE International Exhibition of Electricity, organised in celebration of the Volta centenary, was opened at Como on Saturday by King Humbert. His Majesty also opened a national silk industry exhibition, connected with the electrical exhibition. Switzerland was officially represented at the ceremony, and there were also present the Bishop of Como, the Senators and Deputies representing the province in the Italian Parliament, some members of the family of Volta, who was born at Como, a number of scientific celebrities, and a large attendance of the general public. Speeches were delivered by the Mayor, the presidents of the two exhibitions, and Signor Salandra, the Minister of Agriculture, who dwelt on the progress made by Italy in the silk-growing industry.

AN international congress dealing with the prevention and cure of tuberculosis was opened in Berlin yesterday. The Emperor and Empress of Germany are taking the greatest

NO. I 543 , VOL. 6o] interest in the congress, and her Majesty attended in person at the formal opening of the proceedings in the great hall of the Reichstag by the Duke of Ratibor. Some of the foreign delegates will be presented to the Emperor on Sunday after the termination of the congress. Owing to the Whitsuntide recess, the congress will have the use of the whole of the Reichstag buildings. The Times correspondent at Berlin reports that on Tuesday night there was an informal reception of the members and delegates by Princess Elizabeth of Hohenlohe in the main gallery of the Reichstag. The congress will be attended by nearly 2000 persons, including 112 foreign delegates and a great number of unofficial foreign members.

IT is announced in Science that Mr. Edward H. Harriman, of New York, has invited a number of scientific men to accom. pany him as his guests on an expedition to Alaska. The party will leave Seattle about the end of May, on a large steamer chartered and fitted up specially for the expedition. They expect to take the "inside passage" route to Lynn Canal, and then, after visiting Sitka, proceed westward along the coast to Yakutat Bay, Prince William Sound, Cook's Inlet and Kadiak Island. Numerous places will be visited which are out of reach of ordinary travellers, and stops will be made to admit of scientific work. Steam launches, tents, camp outfit, packers, $\& c$, have been bountifully provided, so that the largest amount of work may be done in the shortest time.

Prof. S. P. Thompsen, F.R.S., will be the president of the Institution of Electrical Engineers for the ensuing session.

Prof. J. A. Fleming, F.R.S., will deliver one of the evening lectures during the meeting of the British Association at Dover in September. He has selected as his subject, "The Centenary of the Electric Current."

THE steamship Antarctic, with the members of Prof. Nathorst's Expedition on board, left Stockholm on Saturday for the east coast of Greenland in search of Herr Andrée and his two companions.

THE Russian members of the Russo-Swedish Expedition for taking meridian measurements at Spitsbergen, left St. Petersburg on Sunday. The leader of the expedition is Captain Sergieffsky.

Mr. R. W. Forsyth, Royal College of Science, South Kensington, has been appointed official reporter to the Physical Society.

A $\Upsilon$ the last ordinary meeting of the Midland Malacological Society, held in Mason University College, Birmingham, on May I2, the president, Mr. Walter E. Collinge, in the chair, Dr. Henry Fischer, of Paris, and Prof. H. A. Pilsbry, of Philadelphia, Pa., U.S.A., were both elected honorary members of the Society.

THE announcement of the death of Mr. G. F. Lyster at the age of seventy-six will be received with regret in engireering circles. Mr. Lyster was for a long period engineer-in-chief to the Mersey Docks and Harbour Board. He was a dock engineer of great skill and resource, and not the least of his achievements was the designing of a system of sluicing by which the docks on the Liverpool side of the river were pro. vided with deep sills and approaches-an advantage which up to his time it was not considered practicable to secure. Mr. Lyster, who on retiring a few years ago was succeeded by his son, became a member of the Institution of Civil Engineers in 1858 , and of the Royal Society of Edinburgh in $\mathbf{I} 886$.

In the House of Lords on Thursday last, Lord Harris moved the second reading of the Oysters Bill, which provides that it shall be the duty of every county and borough council to ascer- 